\title{
The Paleobiolinguistics of Maize (Zea mays L.)
}

\author{
Cecil H. Brown ${ }^{1 *}$, Charles R. Clement ${ }^{2}$, Patience Epps ${ }^{3}$, Eike Luedeling ${ }^{4}$, and Søren Wichmann ${ }^{5}$ \\ Author address: ${ }^{1}$ Northern Illinois University, DeKalb, IL 60115, USA, ${ }^{2}$ Instituto Nacional de Pesquisas da Amazônia, Manaus, \\ AM, Brazil, ${ }^{3}$ University of Texas at Austin, Austin, TX, USA, ${ }^{4}$ World Agroforestry Centre (ICRAF), Nairobi, Kenya, ${ }^{5}$ Max Planck \\ Institute for Evolutionary Anthropology, Leipzig, Germany, and Kazan Federal University, Kazan, Russia \\ "Corresponding author: brown.cecil@yahoo.com
}

Received: June 26, 2013

Volume: 5:52-64

Published: May 21, 2014

(C)2014 Society of Ethnobiology

\begin{abstract}
Paleobiolinguistics is used to determine when and where maize (Zea mays L.) developed significance for different prehistoric groups of Native America. Dates and locations of proto-languages for which maize terms reconstruct generally accord with crop-origin and dispersal information from plant genetics and archaeobotany. Paleobiolinguistic and other lines of evidence indicate that human interest in maize was extensive millennia before the widespread development of a villagefarming way of life in the New World.
\end{abstract}

Keywords: Archaeobotany, crop origins, historical linguistics, Native Americans, paleobiolinguistics, plant domestication, plant genetics

Paleobiolinguistics (PBL) employs the comparative method of historical linguistics to reconstruct the biodiversity known to human groups of the unrecorded past (Brown et al. 2013a). ${ }^{1}$ Comparison of words for biological taxa from languages of the same language family facilitates reconstruction of the biological vocabulary of the family's ancient protolanguage. This study uses PBL to establish when and where maize (Zea mays L.) developed significance for different prehistoric groups of Native America. This entails mapping in both time and geographic space proto-languages for which words for maize reconstruct.

This information is provided to supplement croporigin studies of maize from genetics and archaeology. Our paper's primary purpose is to supply PBL data for use by scholars directly and intimately focused on maize origin and dispersal. We do not attempt to flesh out nuanced implications of PBL results, but instead offer only the most general interpretation of our findings for understanding developments in the prehistory of maize, leaving consideration of details suggested by PBL to experts dedicated to the taxon. Our limited interpretive approach continues a practice followed in presentation of PBL data relating to chili pepper and manioc published in preceding Ethnobiology Letters papers (respectively, Brown et al. 2013b and Brown et al. 2013c). ${ }^{2}$

Being the most important cereal crop domesticated in the New World, substantial multidisciplinary attention has been directed to maize's origin, domestication, and dispersal, much of which is covered in a comprehensive anthology by Staller et al. (2006). Among papers included in Staller et al.'s book is Brown (2006a), an early application of the PBL approach that was neither computer-assisted nor provided proto-language homeland cartography. Since the appearance of the latter, software-based methods for dating and locating proto-languages have been developed and are employed here, rendering the present study the most up-to-date and definitive PBL treatment possible. The present study also advances the earlier investigation (Brown 2006a) by expanding the number of proto-languages treated, especially augmenting the pool of proto-languages from South America.

All five species of Zea are native to Mexico and Central America (Buckler and Stevens 2006). Zea mays contains the domesticated populations of maize (Zea mays ssp. mays), its wild ancestor (ssp. parviglumis), and two other subspecies that hybridize with other populations but do not contribute significantly to the 
Table 1. Maize-term reconstruction for proto-languages of North America and Northern Mexico.

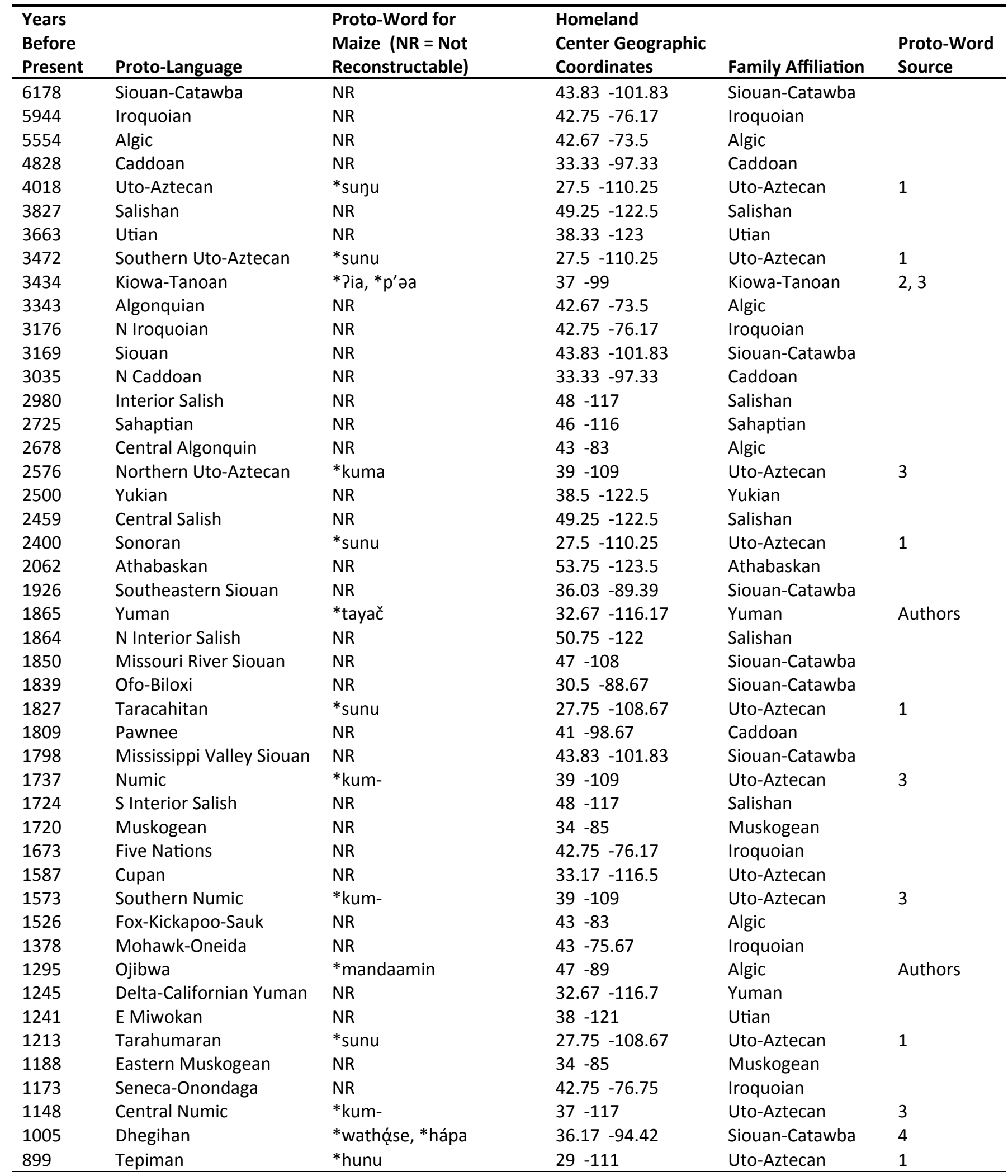

(continued on next page) 
(continued from previous page)

\begin{tabular}{|c|c|c|c|c|c|}
\hline $\begin{array}{l}\text { Years } \\
\text { Before } \\
\text { Present }\end{array}$ & Proto-Language & $\begin{array}{l}\text { Proto-Word for } \\
\text { Maize (NR = Not } \\
\text { Reconstructable) }\end{array}$ & $\begin{array}{l}\text { Homeland } \\
\text { Center Geographic } \\
\text { Coordinates }\end{array}$ & Family Affiliation & $\begin{array}{l}\text { Proto-Word } \\
\text { Source }\end{array}$ \\
\hline 820 & Upland Yuman & *tayač & $34-113.33$ & Yuman & Authors \\
\hline 737 & Dakota & *wahú-apa & $43.83-101.83$ & Siouan-Catawba & 4 \\
\hline 718 & Apachean & *naadaa & $36.58-104$ & Athabaskan & Authors \\
\hline 534 & River Yuman & *tadič & $32.83-114.33$ & Yuman & Authors \\
\hline 345 & W Muskogean & *tanči? & $34-88$ & Muskogean & Authors \\
\hline
\end{tabular}

Proto-Word Source:

1. Stubbs 2011

2. Davis 1989

3. Hill 2008

4. Carter et al. In Preparation

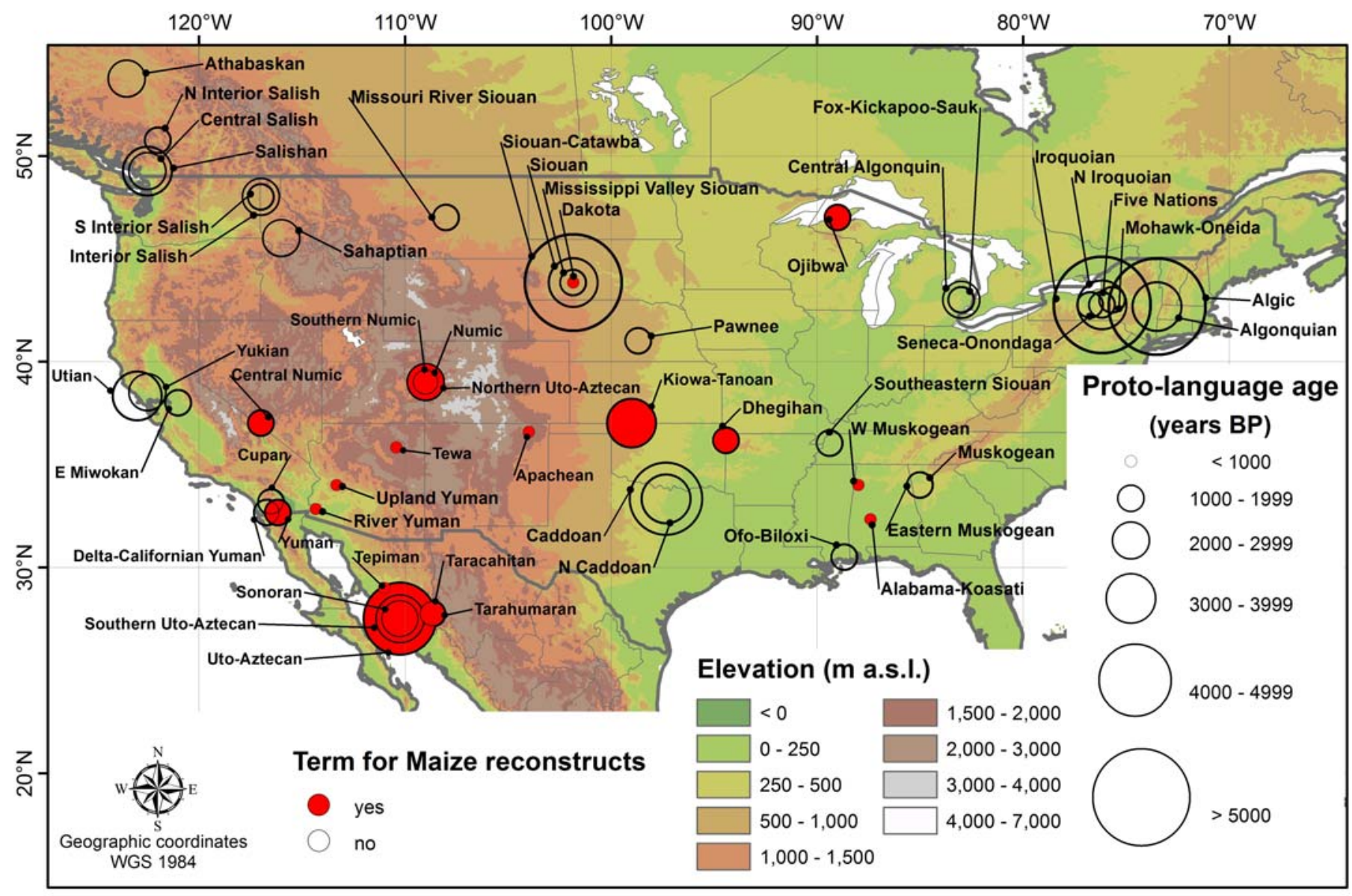

Figure 1. Maize-term reconstruction information from Table 1 plotted on map of North America. 
Table 2. Maize-term reconstruction for proto-languages of Mesoamerica (Southern Mexico and Northern Central America).

\begin{tabular}{|c|c|c|c|c|c|}
\hline $\begin{array}{l}\text { Years } \\
\text { Before } \\
\text { Present }\end{array}$ & Proto-Language & $\begin{array}{l}\text { Proto-Word for Maize } \\
\text { (NR = Not Reconstructable) }\end{array}$ & $\begin{array}{l}\text { Homeland } \\
\text { Center Geographic } \\
\text { Coordinates }\end{array}$ & Family Affiliation & $\begin{array}{l}\text { Proto- } \\
\text { Word } \\
\text { Source }\end{array}$ \\
\hline 6591 & Otomanguean & $*^{*}{ }^{w}$ au, ${ }^{*} s(a 7) a i(n), *^{n u}$ & $18-96.92$ & Otomanguean & 1 \\
\hline 5498 & $\begin{array}{l}\text { Popolocan- } \\
\text { Zapotecan }\end{array}$ & $*$ nu- & $17.17-96.17$ & Otomanguean & Authors \\
\hline 5357 & Amuzgo-Mixtecan & $*$ nu- & $16.92-97.58$ & Otomanguean & Authors \\
\hline 4542 & Mixtecan & *ndi-Өe $(m) 34$ & $16.92-97.58$ & Otomanguean & 2 \\
\hline 4274 & Totozoquen & $*^{*} k^{y} u s ̌ l \sim *^{y} k^{y}{ }^{\prime} s$ & $19.92-97.42$ & Totozoquean & 3 \\
\hline 3654 & Otopamean & $*_{\text {thǫa, }} *_{\text {-sa }}$ & $20.08-100.08$ & Otomanguean & 4 \\
\hline 3149 & Zapotecan & *š-okwa? & $17.17-96.17$ & Otomanguean & 5 \\
\hline 3140 & Mixtec-Cuicatec & $*^{\mathrm{n}} \mathrm{du}$ & $16.92-97.58$ & Otomanguean & 6 \\
\hline 3036 & Popolocan & *na-, ñu-hme & $18-96.92$ & Otomanguean & 2 \\
\hline 2445 & Chiapanec-Mangue & *nuu- & $17.07-92.73$ & Otomanguean & 2 \\
\hline 2220 & Mayan & $*{ }_{i i}^{\prime} m$ & $15.42-91.83$ & Mayan & 7 \\
\hline 2214 & Otomian & *tha & $20.08-100.08$ & Otomanguean & 8 \\
\hline 2209 & Chocho-Popolocan & $*$ nu- & $17.67-97.42$ & Otomanguean & Authors \\
\hline 1935 & Chinantecan & $*^{*} \mathrm{w}_{\mathrm{i}}:{ }^{\mathrm{L}}$ & $17.92-96.5$ & Otomanguean & 9 \\
\hline 1783 & Popoloca & *nuwa & $18-96.92$ & Otomanguean & Authors \\
\hline 1676 & Zapotec & $*_{\text {š-okwa? }}$ & $17.17-96.17$ & Otomanguean & 5 \\
\hline 1649 & Quichean-Mamean & $*_{-i i} m$ & $15.42-91.83$ & Mayan & 7 \\
\hline 1596 & Mixe-Zoquean & *mo:k & $17.22-96.03$ & Totozoquean & 10 \\
\hline 1520 & General Aztec & $* \sin -$ & $18.35-99.83$ & Uto-Aztecan & 11 \\
\hline 1492 & Greater Mamean & $*_{-i}{ }^{\prime} m$ & $15.42-91.83$ & Mayan & 7 \\
\hline 1437 & Mixtec & *noni? & $16.92-97.58$ & Otomanguean & 12 \\
\hline 1435 & Totonacan & *kúši' & $19.92-97.42$ & Totozoquean & 7 \\
\hline 1432 & Cholan-Tzeltalan & $*_{-i i} m$ & $16.83-92.83$ & Mayan & 7 \\
\hline 1225 & Kanjobalan-Chujean & $*_{-i i} m$ & $15.83-91.83$ & Mayan & 7 \\
\hline 1198 & Corachol & $*_{\text {iku }}$ & $22.17-104.83$ & Uto-Aztecan & 13 \\
\hline 1148 & Cholan & $*_{-} \mathrm{ii}^{\prime} \mathrm{m}$ & $14.81-89.38$ & Mayan & 7 \\
\hline 1058 & Chujean & $*_{\text {-i'im }}$ & $15.92-91.58$ & Mayan & 7 \\
\hline 997 & Chatino & *n-sukwà? & $16.25-97.38$ & Otomanguean & 5 \\
\hline 981 & Greater Quichean & $*_{-i i m}$ & $14.78-91.5$ & Mayan & 7 \\
\hline 948 & Subtiaba-Tlapanecan & $* i s ̌ i$ & $17.08-99$ & Otomanguean & Authors \\
\hline 900 & Mixe & *mo:hk & $17.02-96.07$ & Totozoquean & 10 \\
\hline 802 & Kanjobalan & $*_{-i}{ }^{\prime} m$ & $15.83-91.83$ & Mayan & 7 \\
\hline 790 & Yucatecan & $*_{-i} i^{\prime}$ & $20-89$ & Mayan & 7 \\
\hline 787 & Zoque & *mok & $16.9-94.68$ & Totozoquean & 10 \\
\hline 741 & Otomi & *thą & $20.08-100.08$ & Otomanguean & 14 \\
\hline 511 & Tzeltalan & $*$-im & $16.83-92.83$ & Mayan & 7 \\
\hline \multicolumn{2}{|c|}{ Proto-Word Source: } & \multicolumn{4}{|c|}{ 5. Campbell $2013 \quad$ 10. Wichmann 1995} \\
\hline \multicolumn{2}{|c|}{ 1. Kaufman 1990} & \multicolumn{4}{|l|}{ 6. Longacre 1957} \\
\hline \multicolumn{2}{|c|}{ 2. Rensch 1976} & \multirow{2}{*}{$\begin{array}{l}\text { 7. Brown and Wichmann } 2004 \\
\text { 8. Newman and Weitlaner } 1950 \text { b }\end{array}$} & \multicolumn{2}{|c|}{ 12. Josserand 1983} & \\
\hline \multirow{2}{*}{\multicolumn{2}{|c|}{$\begin{array}{l}\text { 3. Brown et al. } 2011 \\
\text { 4. Bartholomew } 1965\end{array}$}} & & \multicolumn{2}{|l|}{ 13. Stubbs 2011} & \\
\hline & & 9. Rensch 1989 & 14. Newman anc & eitlaner 1950a & \\
\hline
\end{tabular}




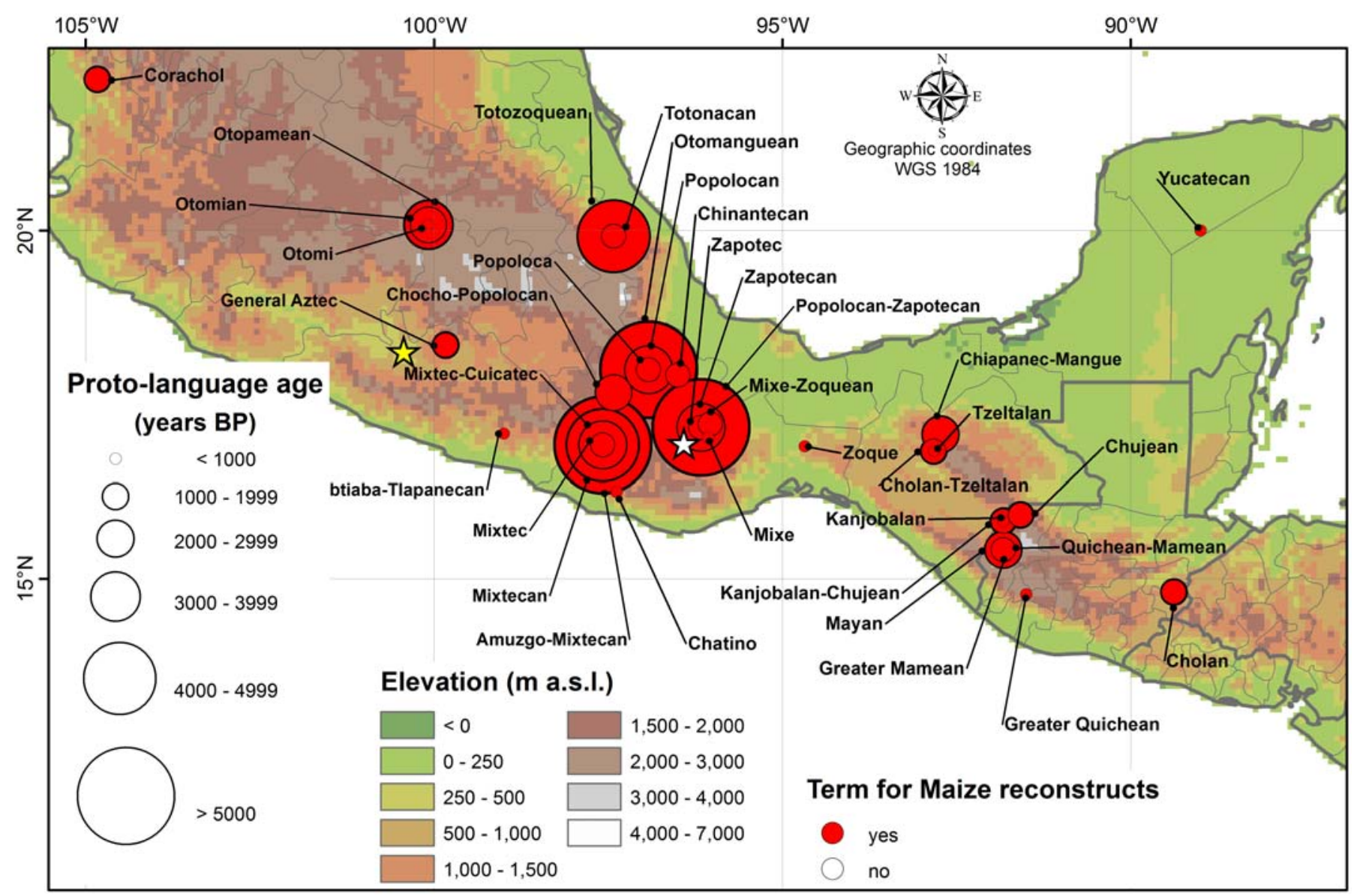

Figure 2. Maize-term reconstruction information from Table 2 plotted on map of Mesoamerica. The yellow star locates the Balsas River valley and the white star locates Guilá Naquitz cave.

domesticated genome (but see Heerwaarden et al. 2011 for the importance of ssp. mexicana). Initial domestication of subspecies mays occurred in the Balsas River valley of southern Mexico from local populations of ssp. parviglumis (Benz 2006; Buckler and Stevens 2006) as early as 9000 BP (Matsuoka et al. 2002; Heerwaarden et al. 2011). The earliest microbotanical evidence dates the crop to $8700 \mathrm{BP}$ in the Balsas River valley (Piperno et al. 2009) and the earliest macrobotanical evidence to $6200 \mathrm{BP}$ at Guilá Naquitz cave, Mexico (Piperno and Flannery 2001). From the Balsas River valley, maize spread both north and south, reaching the U.S. Southwest by 3200 BP, the Eastern U.S. by 2300 BP (Hart et al. 2007), the inter-Andean valleys of Colombia by 7500 BP, northern coastal Peru by 6500 BP (Grobman et al. 2012), and lowland Amazonian Ecuador by 6000 BP (Piperno 2011). Molecular genetic analyses confirm the dispersal from southern Mexico into the southwestern U.S. and then into the northern U.S. ${ }^{3}$ The southward dispersal led to a split into two major genetic groups, an Andean and a lowland South American group (Matsuoka et al. 2002; Vigouroux et al. 2008; Heerwaarden et al. 2011).

Much of maize's dispersal occurred well before it developed as a staple crop between 3000 and 2000 BP (Blake 2006; Piperno 2011), suggesting that it was only a minor crop, perhaps having uses other than general consumption. Iltis (2000) hypothesizes that sugar in the plant's stem was initially more important than its kernel, an idea elaborated by Smalley and Blake (2003) with the proposal that maize was first used to produce an alcoholic beverage. Detection of abundant kernel starch grains at the site of early domestication, and lack of stalk phytoliths (Piperno et al. 2009) weaken support for this proposal. Sugar is the basis for fermentation, and can be produced from kernel starch as well as from the stem. Consequently, kernel starch might have been selected for fermentation relating to gifting and feasting events (Bonzani and Oyuela- 
Table 3. Maize-term reconstruction for proto-languages of Southern Central America and South America.

\begin{tabular}{|c|c|c|c|c|c|}
\hline $\begin{array}{l}\text { Years } \\
\text { Before } \\
\text { Present }\end{array}$ & Proto-Language & $\begin{array}{l}\text { Proto-Word for } \\
\text { Maize (NR = Not } \\
\text { Reconstructable) } \\
\end{array}$ & $\begin{array}{l}\text { Homeland } \\
\text { Center Geographic } \\
\text { Coordinates }\end{array}$ & Family Affiliation & $\begin{array}{l}\text { Proto-Word } \\
\text { Source }\end{array}$ \\
\hline 7266 & Macro-Ge & NR & $-11.3-53$ & Macro-Ge & \\
\hline 4701 & Mataco-Guaykuru & NR & $-22.5-62.58$ & Mataco-Guaykuru & \\
\hline 4461 & Southern Arawakan & *šinki & $-10.33-74.33$ & Arawakan & Authors \\
\hline 4400 & Chibchan & *eba & $9.75-83.42$ & Chibchan & 1 \\
\hline 4134 & Arawakan & *marikł & $1-69.17$ & Arawakan & 2 \\
\hline 4085 & N Arawakan & *mariki & $1-69.17$ & Arawakan & Authors \\
\hline 3943 & Panoan-Tacanan & *žikí, $*$ žłki & $-7.5-75$ & Panoan-Tacanan & 3 \\
\hline 3585 & Tupi & NR & $-8-62$ & Tupi & \\
\hline 3518 & Caribbean N Arawakan & *mariki & $12-72$ & Arawakan & Authors \\
\hline 3310 & Salivan & *n`amo & $5-67$ & Salivan & Authors \\
\hline 3241 & Barbacoan & *pijo & $0.67-79$ & Barbacoan & 4 \\
\hline 3196 & Wapishanan & *mariki & $1-59$ & Arawakan & Authors \\
\hline 3178 & Zaparoan & *sauku & $-3.25-74$ & Zaparoan & 5 \\
\hline 3124 & Nadahup & NR & $0-69$ & Nadahup & \\
\hline 3023 & $\mathrm{Ge}$ & NR & $-15-52.5$ & Macro-Ge & \\
\hline 2927 & Witoto-Ocaina & NR & $-2.75-71.75$ & Witoto-Ocaina-Nonuya & \\
\hline 2909 & Guaykuruan & NR & $-26.5-59$ & Mataco-Guaykuru & \\
\hline 2807 & Nambiquaran & ${ }^{*} \mathrm{ka}^{3} \mathrm{y} \underline{\mathrm{at}} \mathrm{t}^{3}$ & $-13-59$ & Nambiquaran & 6 \\
\hline 2774 & Misumalpan & *aja & $13-84.5$ & Misumalpan & 1 \\
\hline 2765 & Zamucoan & NR & $-20.25-59.25$ & Zamucoan & \\
\hline 2731 & Talamancan & $*_{\mathrm{ipo}} \sim *_{\mathrm{ik}}{ }^{\mathrm{w}} \mathrm{o}$ & $9.75-83.42$ & Chibchan & Authors \\
\hline 2699 & Tucanoan & ${ }^{*}$ we'a & $0.33-70.25$ & Tucanoan & 7 \\
\hline 2593 & Inland N Arawakan & *(ma)kaanhai & $1-69.17$ & Arawakan & 8 \\
\hline 2503 & Venezuelan Cariban & *ana- & $6.5-66$ & Cariban & Authors \\
\hline 2433 & Southern Guaykuruan & NR & $-26.5-59$ & Mataco-Guaykuru & \\
\hline 2414 & North Barbacoan & *pija & $1.5-78.25$ & Barbacoan & Authors \\
\hline 2412 & Cariban & $*_{-n a-}$ & $10.17-72.75$ & Cariban & 9 \\
\hline 2404 & Matacoan & *iphAtha & $-22.5-62.58$ & Mataco-Guaykuru & 10 \\
\hline 2271 & Boran & NR & $-2.17-72.33$ & Boran & \\
\hline 2258 & Chocoan & *pe & $6.83-77.17$ & Chocoan & Authors \\
\hline 2219 & Purus & *šiki & $-12.5-69.33$ & Arawakan & Authors \\
\hline 2156 & Western Tucanoan & *we'a & $-2.83-72.5$ & Tucanoan & Authors \\
\hline 1931 & Chapacuran & *mapak & $-13.42-63.17$ & Chapacuran & 11 \\
\hline 1853 & Panoan & *šiki, *šiki & $-7.5-75$ & Panoan-Tacanan & Authors \\
\hline 1853 & Pekodian & $*$-nat & $-14-55$ & Cariban & Authors \\
\hline 1850 & Tupari & *atsitsi & $-12.5-62.5$ & Tupi & 12 \\
\hline 1821 & Southern Ge & *gãr & $-26-52$ & Macro-Ge & 13 \\
\hline 1764 & Arauan & *kimi & $-6-70.5$ & Arauan & 14 \\
\hline 1717 & Quechuan & *sara & $0.33-78$ & Quechuan & 15 \\
\hline 1712 & Monde & *maek & $-10.97-61.13$ & Tupi & Authors \\
\hline 1647 & Bolivia-Parana & *soporo & $-15.17-65.42$ & Arawakan & Authors \\
\hline 1634 & Mainline Panoan & *šiki & $-7.5-75$ & Panoan-Tacanan & 16 \\
\hline 1607 & Yabuti & *čiči & $-12.25-62.25$ & Macro-Ge & Authors \\
\hline 1590 & Tacanan & *jike & $-13.33-66.5$ & Panoan-Tacanan & 3 \\
\hline 1569 & Harakmbet & NR & $-12.5-70.5$ & Harakmbet & \\
\hline 1550 & Tupi-Guarani & *aßati & $-8 \quad-62$ & Tupi & 17 \\
\hline
\end{tabular}

(continued on next page) 
(continued from previous page)

\begin{tabular}{|c|c|c|c|c|c|}
\hline $\begin{array}{l}\text { Years } \\
\text { Before } \\
\text { Present }\end{array}$ & Proto-Language & $\begin{array}{l}\text { Proto-Word for } \\
\text { Maize (NR = Not } \\
\text { Reconstructable) }\end{array}$ & $\begin{array}{l}\text { Homeland } \\
\text { Center Geographic } \\
\text { Coordinates }\end{array}$ & Family Affiliation & $\begin{array}{l}\text { Proto-Word } \\
\text { Source }\end{array}$ \\
\hline 1520 & Chipaya-Uru & $*$ tura & $-19-68.4$ & Chipaya-Uru & Authors \\
\hline 1519 & Kampan & *šinki & $-10.33-74.33$ & Arawakan & Authors \\
\hline 1480 & Mundurucu & *muira & $-7-55.57$ & Tupi & Authors \\
\hline 1418 & Cayapa-Colorado & *pijo & $0.67-79$ & Barbacoan & Authors \\
\hline 1402 & Guianan Cariban & $*$-na- & $3.25-55.75$ & Cariban & Authors \\
\hline 1395 & Cabecar-Bribri & *ikwo & $9.42-83$ & Chibchan & Authors \\
\hline 1335 & Kakua-Nukak & NR & $0.88-69.56$ & Kakua-Nukak & \\
\hline 1319 & Yanomam & NR & $3.5-62.83$ & Yanomam & \\
\hline 1291 & Guahiban & *hétsa & $6.5-71.33$ & Guahiban & 18 \\
\hline 1241 & Eastern Tucanoan & *we'a & $0.33-70.25$ & Tucanoan & Authors \\
\hline 1185 & Kawapanan & *čipti? & $-5.5-77$ & Kawapanan & 19 \\
\hline 1169 & Pemongan & *anaik & $4-60$ & Cariban & 9 \\
\hline 992 & Taranoan & *a:naci & $1-73$ & Cariban & 20 \\
\hline 974 & Quechua II & *sara & $0.33-78$ & Quechuan & 15 \\
\hline 875 & Embera & *pe & $5.25-76.66$ & Chocoan & Authors \\
\hline 678 & Jivaroan & *šaa & $-2.5-78$ & Jivaroan & Authors \\
\hline 609 & Araucanian & *wa- & $-38-72$ & Araucanian & Authors \\
\hline 419 & Coconucan & *pura- & $2.5-76.5$ & Barbacoan & Authors \\
\hline 414 & Witoto Proper & *beǰa & $-1-73.5$ & Witoto-Ocaina-Nonuya & Authors \\
\hline 389 & Mayoruna Panoan & *šik(š)u & $-4.42-70.25$ & Panoan-Tacanan & Authors \\
\hline \multicolumn{2}{|c|}{ Proto-Word Source: } & \multicolumn{2}{|c|}{ 7. Thiago Chacon per. com. } & n 2004 & \\
\hline \multicolumn{2}{|c|}{ 1. Constenla 1990} & \multicolumn{2}{|l|}{ 8. Ramirez 2001} & m Adelaar per.com. & \\
\hline \multicolumn{2}{|c|}{ 2. Payne 1991} & \multicolumn{2}{|c|}{ 9. Sergio Meira per. com. } & 2008 & \\
\hline \multicolumn{2}{|c|}{ 3. Girard 1971} & \multicolumn{2}{|l|}{ 10. Najlis 1984} & o 2010 & \\
\hline \multicolumn{2}{|c|}{ 4. Curnow and Liddicoat 1998} & \multicolumn{2}{|c|}{ 11. Angenot-de Lima 1997} & stian and Matteson 1972 & \\
\hline \multicolumn{2}{|c|}{ 5. Lev Michael, per. com. } & \multicolumn{2}{|c|}{ 12. Moore and Galucio 1994} & Valenzuela per. com. & \\
\hline \multicolumn{2}{|c|}{ 6. Price 1978} & \multicolumn{2}{|l|}{ 13. Jolkesky 2010} & a 2000 & \\
\hline
\end{tabular}

Caycedo 2006; Benz and Staller 2006), a possible explanation of maize's use before becoming a food staple.

Maize-term reconstructions are presented for proto-languages of three major regions of the New World: (1) North America and Northern Mexico (Table 1); (2) Southern Mexico and Northern Central America (henceforth Mesoamerica) (Table 2); and (3) Southern Central America and South America (Table 3). The tables list major proto-languages of the Americas widely regarded by historical linguists as demonstrated. Some major proto-languages are not included because lexical information from daughter languages is not sufficiently available for drawing either positive or negative conclusions about maizeterm reconstruction. In addition to identifying proto- languages with maize terms and the terms themselves, the tables report proto-languages for which these terms are "not reconstructable" (NR). NR is a designation used when terms for maize are present in all or most languages of a family, but, nonetheless, are not cognate and, hence, do not attest to a maize term in their shared ancestral language. NR, then, never indicates non-reconstructibility because of missing data. 4

Dates for proto-languages presented in the tables are intended to be the latest dates at which these languages were spoken (just before breaking up into daughter languages). These are calculated through use of Automated Similarity Judgment Program (ASJP) chronology, a computational dating approach based on the lexical similarity of languages (Holman et al. 


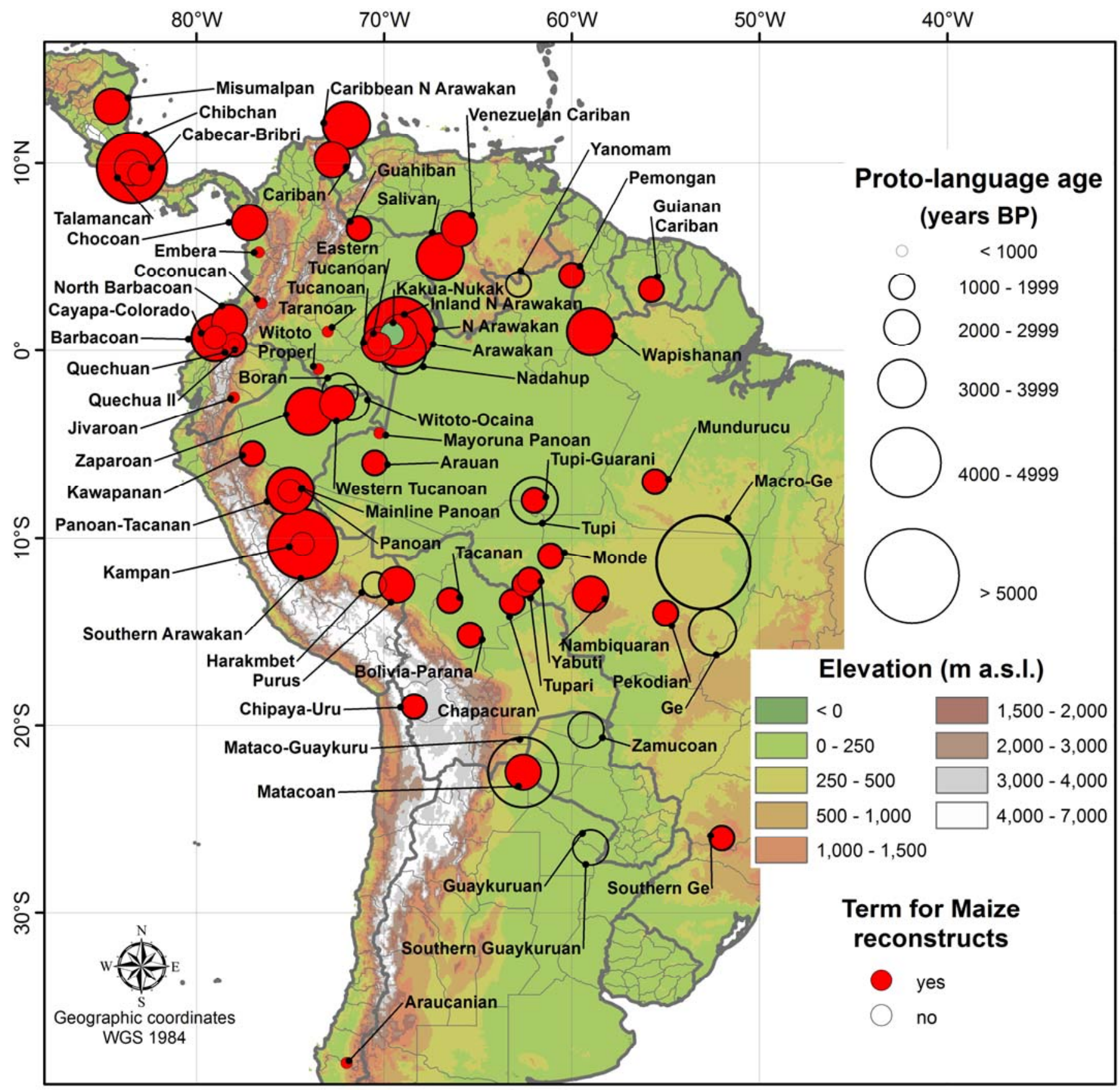

Figure 3. Maize-term reconstruction information from Table 3 plotted on map of Southern Central America and South America.

2011). ${ }^{5}$ Possible geographic coordinates for protolanguage homeland centers given in the tables are produced through automation using an algorithm for identifying the maximum lexical diversity within a language family (Wichmann et al. 2010). The geographic center of lexical diversity of a family is assumed to correlate with where the family's protolanguage was spoken. Tables also give a linguistic family affiliation for each proto-language. The information reported in Tables 1,2 and 3 is plotted on maps of Figures 1, 2, 3 and 4 to give a visual perspective on both the chronological and geographic 


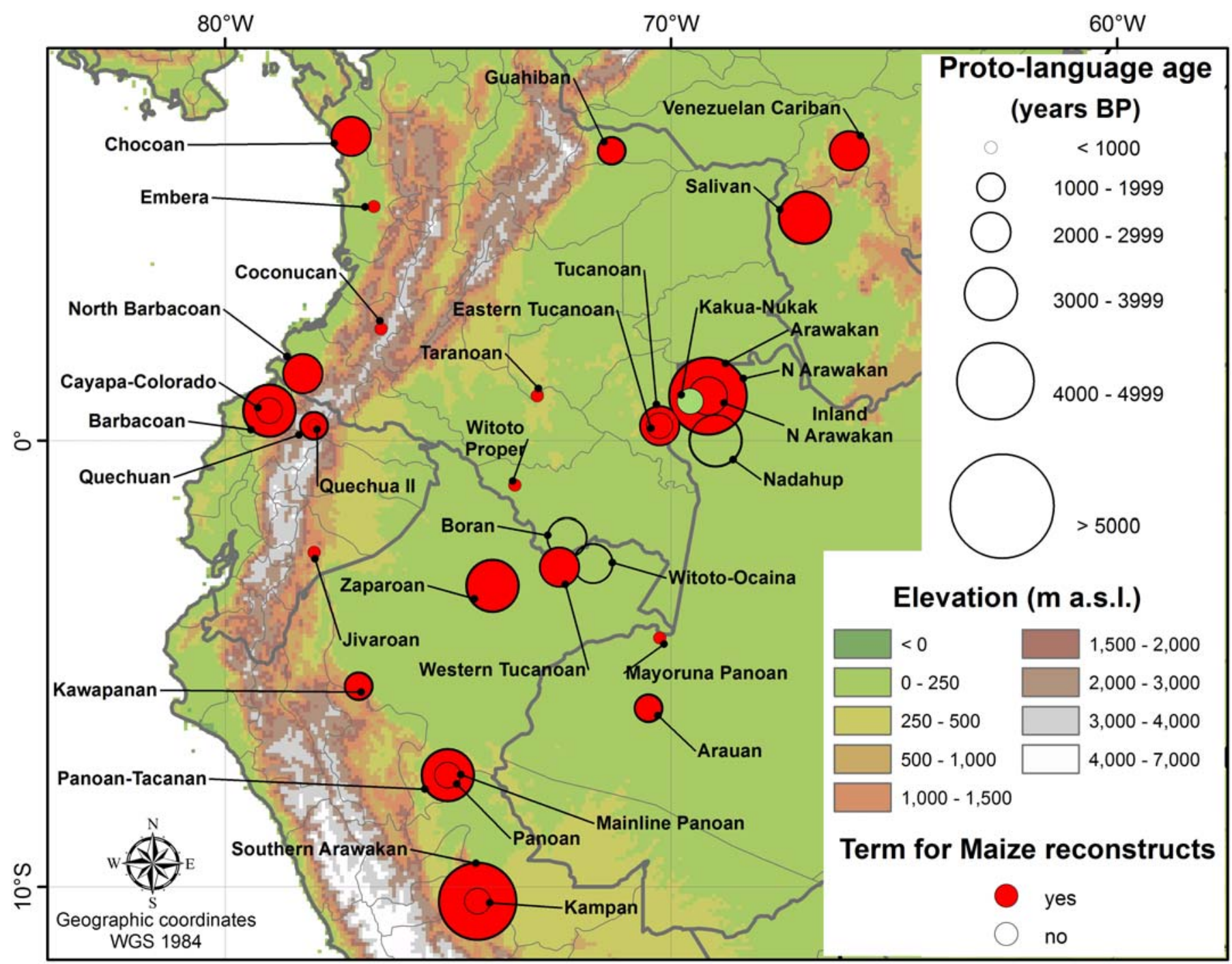

Figure 4. Enlargement of congested region (northwestern South America and adjacent areas) of map of Figure 3.

distributions of reconstructed maize terms. Figure 4 is an enlargement of a highly congested area of the map of Figure 3.

PBL findings reported here are offered as a resource for scholars of maize prehistory interested in pursuing lines of evidence in addition to those provided by genetics and archaeology. While we leave consideration of details suggested by PBL to those with specialized knowledge of the origin and dispersal of maize, we can observe now that PBL chronological and geographic determinations for Zea mays L. generally accord with preceding observations relating to the time and place of its domestication, and to subsequent dispersal. For example, the homeland of the oldest ancestral language showing a reconstructed maize term, Proto-Otomanguean (6591 BP), is in southern Mexico, not far from the postulated area of maize's domestication in the Balsas River valley (Benz 2006; Buckler and Stevens 2006; Matsuoka et al. 2002; Heerwaarden et al. 2011) and the Guilá Naquitz cave in Oaxaca from which the earliest macro-botanical examples of maize (6200 BP) have been retrieved (Blake 2006) (see stars on the map of Figure 2 locating these two sites). PBL determinations also mirror the archaeologically attested early appearance of the crop in South America (Piperno et al. 2011), and its relatively late manifestation in the Eastern U.S. (Hart and Lovis 2013). Generally, proto-languages for which maize terms reconstruct are broadly distributed in the Americas, reflecting the crop's substantial dispersal from its origin in southwestern Mexico. ASJP dates for these proto-languages, like archaeobo- 
tanical ones, indicate that domestication and dispersal of the crop occurred before the general development of a village-farming way of life in the New World from 4000 to 3000 BP (Piperno and Pearsall 1998) and before maize became a major food crop after 3000 BP (Blake 2006).

\section{Acknowledgements}

Our gratitude goes to Willem Adelaar, Thiago Chacon, Bernard Comrie, Sergio Meira, Lev Michael, and Pilar Valenzuela for sharing data and insights, and to Dolores R. Piperno and Yves Vigouroux for critical suggestions to improve the archaeological and genetic associations. We also thank three anonymous reviewers for their insightful comments.

\section{Declarations}

Permissions: Not applicable.

Sources of funding: Epps' work on this project was supported by the National Science Foundation (HSD0902114).

Conflicts of interest: None declared.

\section{References Cited}

Angenot de Lima, G. 1997. Fonotática e Fonologia do Lexema Protochapakura. Unpublished Master's Thesis, Universidade Federal de Rondônia, Guajara-Mirim, Rondônia.

Bartholomew, D. A. 1965. The Reconstruction of Otopamean (Mexico). Unpublished Doctoral Dissertation, Department of Linguistics, The University of Chicago, Chicago, Illinois.

Benz, B. F. 2006. Maize in the Americas. In Histories of Maize: Multidisciplinary Approaches to the Prehistory, Biogeography, Domestication, and Evolutions of Maize, edited by J. E. Staller, R. H. Tykot, and B. F. Benz, pp. 9-20. Elsevier, San Diego, CA.

Benz, B. F., and J. E. Staller. 2006. The Antiquity, Biogeography, and Culture History of Maize in the Americas. In Histories of Maize: Multidisciplinary Approaches to the Prehistory, Biogeography, Domestication, and Evolutions of Maize, edited by J. E. Staller, R. H. Tykot, and B. F. Benz, pp. 665-673. Elsevier, San Diego, CA.

Blake, M. 2006. Dating the Initial Spread of Zea mays. In Histories of Maize: Multidisciplinary Approaches to the Prehistory, Biogeography, Domestication, and Evolutions of Maize, edited by J. E. Staller, R. H.
Tykot, and B. F. Benz, pp. 55-72. Elsevier, San Diego, CA.

Bonzani, R. M., and A. Oyuella-Caycedo. 2006. The Gift of the Variation and Dispersion of Maize: Social and Technological Context in Amerindian Societies. In Histories of Maire: Multidisciplinary Approaches to the Prehistory, Biogeography, Domestication, and Evolutions of Maize, edited by J. E. Staller, R. H. Tykot, and B. F. Benz, pp. 343-356. Elsevier, San Diego, CA.

Brown, C. H. 2006. Glottochronology and the Chronology of Maize in the Americas. In Histories of Maize: Multidisciplinary Approaches to the Prehistory, Biogeography, Domestication, and Evolutions of Maize, edited by J. E. Staller, R. H. Tykot, and B. F. Benz, pp. 648-663. Elsevier, San Diego, CA.

Brown, C. H., D. Beck, G. Kondrak, J. K. Watters, and S. Wichmann. 2011. Totozoquean. International Journal of American Linguistics 77: 323-372.

Brown, C. H., E. Luedeling, S. Wichmann, and P. Epps. 2013a. The Paleobiolinguistics of Domesticated Squash (Cucurbita spp.). In Explorations in Ethnobiology: The Legacy of Amadeo Rea, edited by M. Quinlan and M. D. Lepofsky, pp. 132-161. Society of Ethnobiology, Denton, TX.

Brown, C. H., C. R. Clement, P. Epps, E. Luedeling, and S. Wichmann. 2013b. The Paleobiolinguistics of Chili Pepper (Capsicum spp.). Ethnobiology Letters 4:111.

Brown, C. H., C. R. Clement, P. Epps, E. Luedeling, and S. Wichmann. 2013C. The Paleobiolinguistics of Domesticated Manioc (Manihot esculenta). Ethnobiology Letters 4:61-70.

Brown, C. H., and S. Wichmann. 2004. Proto-Mayan Syllable Nuclei. International Journal of American Linguistics 70:128-186.

Buckler, E. S., and N. M. Stevens. 2006. Maize Origens, Domestication, and Selection. In Darwin's Harvest: New Approaches to the Origin, Evolution, and Conservation of Crops, edited by T. J. Motley, N. Zerega, and H. Cross, pp. 67-91. Columbia University Press, New York.

Campbell, E. 2013. The Internal Diversification and Subgrouping of Chatino. International Journal of American Linguistics 79:395-420.

Campbell, L. and R. W. Langacker. 1978. Proto- 
Aztecan Vowels: Part III. International Journal of American Linguistics 44:262-279.

Carter, R. T., A. W. Jones, J. E. Koontz, R. L. Rankin, and D. S. Rood. In Preparation. Comparative Siouan Dictionary. Computer database from the University of Colorado, Denver.

Christian, D. R., and E. Matteson. 1972. Proto Guahiban. In Comparative Studies in Amerindian Languages, edited by E. Matteson et al., pp. 150-159. Mouton, The Hague.

Constenla-Umaña, A. 1990. Una Hipótesis sobre la Localización del Protochibcha y la Dispersión de sus Descendientes. Revista de Filología y Lingüística de la Universidad de Costa Rica 16:111-123.

Curnow, T. J., and A. J. Liddicoat. 1998. The Barbacoan Languages of Colombia and Ecuador. Anthropological Linguistics 40:384-408.

Davis, I. 1989. A New Look at Aztec-Tanoan. In General and Amerindian Ethnolinguistics: In Remembrance of Stanley Newman, edited by M. R. Key and H. M. Hoenigswald, pp. 365-790. Mouton de Gruyter, Berlin.

Dixon, R. M. W. 2004. Proto-Arawá Phonology. Anthropological Linguistics 46:1-83.

Girard, V. 1971. Proto-Takanan Phonology. University of California Press, Berkeley.

Grobman, A., D. Bonavia, T. D. Dillehay, D. R. Piperno, J. Iriarte, and I. Holst. 2012. Preceramic Maize from Paredones and Huaca Prieta, Peru. Proceedings of the National Academy of Sciences USA 109:1755-1759.

Hart, J. P., H. J. Brumbach, and R. Lusteck. 2007. Extending the Phytolith Evidence for Early Maize (Zea mays ssp. mays) and Squash (Cucurbita sp.) in Central New York. American Antiquity 72:563-583.

Hart, John P., and W. A. Lovis. 2013. Reevaluating What We Know About the Histories of Maize in Northeastern North America: A Review of Current Evidence. Journal of Archaeological Research 21:175216.

van Heerwaarden, J., J. Doebley, W. H. Briggs, J. C. Glaubitz, M. M. Goodman, J. J. Sanchez Gonzalez, and J. Ross-Ibarra. 2011. Genetic Signals of Origin, Spread, and Introgression in a Large Sample of Maize Landraces. Proceedings of the National Academy of Sciences USA 108(3):1088-1092.
Hill, J. H._2007. The Proto-Uto-Aztecan Cultivation Hypothesis: New Linguistic Evidence. Invited paper presented at the 33rd Annual Meeting of the Berkeley Linguistics Society, Berkeley, CA.

Holman, E. W., C. H. Brown, S. Wichmann et al. 2011. Automated Dating of the World's Language Families based on Lexical Similarity. Current Anthropology 52:841-875.

Iltis, H. H. 2000. Homeotic Sexual Translocations and the Origin of Maize (Zea mays, Poaceae): A New Look at an Old Problem. Economic Botany 54:7-42.

Jolkesky, M. P. V. 2010. Reconstrução Fonológica e Lexical do Proto-Jê Meridional. Unpublished Master's Thesis, Universidade Estadual de Campinas, Campinas, SP.

Josserand, J. K. 1983. Mixtec Dialect History. Unpublished Ph.D. Dissertation, Tulane University, New Orleans, LA.

Kaufman, T. S. 1990. Early Otomanguean Homeland and Cultures: Some Premature Hypotheses. University of Pittsburgh Working Papers in Linguistics 1:91-136.

Longacre, R. E. 1957. Proto-Mixtecan. International Journal of American Linguistics 23, supplement. Bloomington, Indiana.

Matsuoka, Y., Y. Vigouroux, M. M. Goodman, J. Sanchez G., E. Buckler, and J. Doebley. 2002. A Single Domestication for Maize Shown by Multilocus Microsatellite Genotyping. Proceedings of the National Academy of Sciencies USA 99:6080-6084.

Meira, S. 2000. A Reconstruction of Proto-Taranoan: Phonology and Morphology. Lincom Europa, München, Germany.

Mello, A. A. S. 2000. Estudo histórico da familía linguística Tupi-Guaraní. PhD dissertation, Universidade Federal de Santa Catarina.

Moore, D. and A. V. Galucio. 1994. Reconstruction of Proto-Tupari Consonants and Vowels. In Survey of California and Other Indian Languages, Report 8: Proceedings of the Meeting of the Society for the Study of the Indigenous Languages of the Americas July 2-4, 1993 and the Hokan-Penutian Workshop July 3, 1993, edited by M. Langdon, pp. 119-137. Berkeley: Dept. of Linguistics, University of California, Berkeley.

Najlis, E. L. 1984. Fonología de la Protolengua Mataguaya. 
Universidad de Buenos Aires, Buenas Aires, Argentina.

Newman, S., and R. Weitlaner. 1950a. Proto-Otomi Reconstructions. International Journal of American Linguistics 16:1-19.

Newman, S., and R. Weitlaner. 1950b. Central Otomian II: Primitive Central Otomian Reconstructions. International Journal of American Linguistics 16:73-81.

Payne, D. L. 1991. A Classification of Maipuran (Arawakan) Languages Based on Shared Lexical Retentions. [In] Handbook of Amazonian Languages, [edited by D. Derbyshire and G. Pullum], 3:355499.

Piperno, D. R. 2011. The Origins of Plant Cultivation and Domestication in the New World Tropics: Patterns, Process, and New Developments. In The Beginnings of Agriculture: New Data, New Ideas, edited by D. Price and O. Bar-Yosef. Current Anthropology 52 (S4):S453-470.

Piperno, D. R., and K. V. Flannery. 2001. The Earliest Archaeological Maize (Zea mays L.) from Highland Mexico: New Accelerator Mass Spectrometry Dates and Their Implications. Proceedings of the National Academy of Sciences USA 98(4):21012104.

Piperno, D. R., and D. M. Pearsall. 1998. The Origins of Agriculture in the Lowland Neotropics. Academic Press, San Diego, CA.

Piperno, D. R., A. J. Ranere, I. Holst, J. Iriarte, and R. Dickau. 2009. Starch Grain and Phytolith Evidence for Early Ninth Millennium B.P. Maize from the Central Balsas River Valley, Mexico. Proceedings of the National Academy of Sciences USA 106:5019-5024.

Price, P. D. 1978. The Nambiquara Linguistic Family. Anthropological Linguistics 20:14-37.

Ramirez, H. 2001. Linguas Arawak da Amazânia Setentrional. Editora da Universidade do Amazonas, Manaus, AM.

Rensch, C. R. 1976. Comparative Otomanguean Phonology. Indiana University Publications, Bloomington, IN.

Rensch, C. R. 1989. An Etymological Dictionary of the Chinantec Languages. Summer Institute of Linguistics, Arlington, TX.

Shell, O. A. 2008. Estudios Pano III: Las Lenguas Pano y su Reconstrucción. Instituto Lingüístico de Verano, Lima, Peru.

Smalley, J., and M. Blake. 2003. Sweet Beginnings: Stalk Sugar and the Domestication of Maize. Current Anthropology 44:675-703.

Staller, J. E., R. H. Tykot, and B. F. Benz, eds. 2006. Histories of Maize: Multidisciplinary Approaches to the Prehistory, Biogeography, Domestication, and Evolutions of Maize. Elsevier, San Diego, CA.

Stubbs, B. D. 2011. Uto-Aztecan: A Comparative Vocabulary. Shumway Family History Services, Flower Mound, TX.

Vigouroux, Y., J. C. Glaubitz, Y. Matsuoka, M. M. Goodman, J. Sánchez G., and J. Doebley. 2008. Population Structure and Genetic Diversity of New World Maize Races Assessed by DNA Microsatellites. American Journal of Botany 95:1240-1253.

Wichmann, S. 1995. The Relationship among the MixeZoquean Languages of Mexico. University of Utah Press, Salt Lake City, UT.

Wichmann, S., A. Müller, and V. Velupillai. 2010.

Homelands of the World's Language Families: A

Quantitative Approach. Diachronica 27:247-276.

\section{Biosketch}

Cecil H. Brown is a linguistic anthropologist with interests in ethnobiology, historical linguistics, and Native American languages.

Charles R. Clement is a geneticist studying the origin and domestication of native Amazonian crops, and the ethnobotany associated with anthropogenic soils and other domesticated landscapes.

Patience Epps is a linguist whose work investigates lowland South American languages from historical, typological, and descriptive perspectives.

Eike Luedeling is an agricultural scientist mainly working on the development of holistic analysis methods for agricultural development interventions.

Søren Wichmann specializes in quantitative methods in historical linguistics and Mesoamerican languages. He is General Editor of the journal Language Dynamics and Change.

\section{Notes}

${ }^{1}$ This is the third PBL study published in Ethnobiology Letters, the first treating chili pepper (Brown et al. 
2013b) and the second manioc (Brown et al. 2013c). The method and theory of PBL (and also the PBL of squash) is discussed in detail in Brown et al. (2013a) and briefly summarized in Brown et al. (2013b). Given this coverage, a discussion of PBL method and theory will not be repeated here.

${ }^{2} \mathrm{PBL}$ analysis is in its infancy, so that it is difficult to predict what detailed contributions to crop-origin studies may emerge. Our ultimate goal is to produce a PBL atlas of New World crops that presents maps for as many as 31 different taxa. An anticipation of this proposed work is that distribution of reconstructed words for many different crops across New World proto-languages will show hemispheric patterns revealing areas of intensified domestication activities and crop dispersal that may not be so apparent when crops are considered on a one-by-one basis.

${ }^{3}$ Archaeological dates cited in this paper come from various different sources, some firsthand, others second-party reports. Some are direct radiocarbon dates and some indirect, and it is often difficult if not impossible to determine if calibration is involved. We report all dates as if they were non-calibrated, calendric dates.

${ }^{4} \mathrm{NR}$ should not necessarily be interpreted as indicating that a term for maize did not pertain to a protolanguage and, by implication, that people who spoke the language were not familiar with the taxon. Another possibility is that a maize term did indeed pertain to a proto-language, but that its referent was not especially salient, accounting for the term's failure to survive in offspring languages and, thus, to be reconstructable for the proto-language (cf., Brown et al. 2013a:140).

${ }^{5}$ Occasionally, an ASJP date for a proto-language may be older than a date for its own parent language. For example, Proto-Southern Arawakan (4461 BP) has an ASJP date older than that for Proto-Arawakan (4134 $\mathrm{BP}$. This sometimes occurs in ASJP chronology when a language group's breakup is closely followed in time by the breakup of its immediate subgroup. The attested variability of ASJP dates accounts for this apparent aberrancy (Holman et al. 2011:872). 